\title{
Enhancing the Teaching Skills of the Multi-Grade Teachers through Lesson Study
}

\author{
Souphanh Thephavongsa \\ Salavan Teacher Training College \\ Salavan province, Lao PDR
}

\begin{abstract}
Teaching in the multi-grade class is more difficult than monograde for teachers, however, multi-grade teaching was defined as the best strategy to achieving access to Education For All (EFA) of children especially those from rural areas. Teachers have been working diligently but unmethodical in their classroom. This study aimed to improve and enhance the teachers' professional skills which they have been facing in the classroom through the Lesson study and discuss why most of the teachers did not like to prepare and/or develop lesson plans. There were 100 participants who teach in the multi-grade schools in the Salavan district. The results represented that pre-test scores and posttest scores from two of training groups were significantly different and found that most of teachers do not usually prepare lesson plans. The research findings also determined that a Lesson study can be beneficial to enhance the development the teachers' professional skills.
\end{abstract}

Keywords: Multi-grade teaching; Multi-grade class; Lesson study approach; Development a lesson plan; Training Multi-grade teachers.

\section{Introduction}

Education is an acquisition of knowledge, skills, and attitudes. These goals of education are implemented by teachers whose teaching method is a way to transform this knowledge and experience from teacher to learners. Multi-grade education is one strategy to promote all children's access to education especially in the remote or rural areas. The multi-grade education or multi-grade teaching was implemented many years ago in numerous countries around the world to achieve the goals of the Education For All (EFA). According to the report of the EFA project which was completed in 2015, it was indicated that multi-grade school teaching was considered important in providing access to EFA, and these practices can help many countries reach the EFA targets, Millennium Development Goals (MDGs), and also the national targets (United Nations Educational, Scientific and Cultural Organization[UNESCO], 2015a). However, teaching practice in multi-grade class is still having problems with teachers who 
teach multi-grade as they are still anxious about their techniques and/or teaching skills.

In Lao PDR (Peoples' Democratic Republic) the number of multi-grade class covered $26 \%$ of the classrooms in the primary schools (Ministry of Education and Sports [MoES], 2017). Since 2000, the government and other development partner organizations have improved and developed the quality of teaching for multi-grade schools which aimed to improve the teachers' professional knowledge and skills on multi-grade teaching in particular in order to help teachers at the local village promote all children to have access to a basic education, and also to reform the challenges in the multi-grade teaching. Thus, teachers who teach in multi-grade schools have had specific promotions in order to encourage them to be more active in their work. Most multi-grade teachers have graduated from the primary school teacher program; they have studied teaching in multi-grade classes, called "Multi-grade teaching method". All of them have faced many challenges and on top of that they are responsible for two or three grades. Therefore, to ensure quality of the teaching and learning activities, the government has made efforts to increase the quality of teachers which can make teachers organize the teaching and learning activities to be as efficient as possible. So, for the last twenty years, there were three main organizations which have worked diligently for the multi-grade teaching; Teacher Upgrading Program (TUP) which was supported by the United Nations International Children's Fund (UNICEF), Lao-Australia Basic Education Program (LABEP) which was supported by the AUS-AID, and School of Quality (SoQ) supported by the UNICEF. Since 1992, The TUP has trained and upgraded teachers who have been untrained and unqualified. There were about 4,000 untrained teachers in 11 provinces and 48 districts, the contents of the training were about reviewing the problems of teaching by using action research model (United Nations International Children's Fund [UNICEF], 2000). However, the teaching of the multi-grade class was limited, and the training period quite brief. (Holt, 2012). Then from the year 2001 to 2006, the LABEP trained over 4,000 inservice teachers in multi-grade teaching in the whole country, and at the same time, the project produced the teaching materials including teachers' handbooks, textbooks, and other teaching and learning materials which were supported by the program. Also, practical educational models were adopted especially for the multi-grade classroom (Lao-Australia Basic Education Program [LABEP], 2008). The QoS also improved the quality of teaching of multi-grade schools, as they have implemented for the multi-grade schools only in terms of some contents which involved the standard of the Quality of School (QoS) which introduced the curriculum and lesson plan, as it did not provide much help to deepen the teacher's understanding about how to teach the multi-grade (UNICEF, 2009).

Salavan province is located in the South of Lao PDR, it consists of eight districts (Salavan, Laognam, Wapi, Khongsedone, Lakhonpheng, Toumlan, Taoy and Samoi), and is covered by 10 small ethnic groups. An academic year 2016-2017, there were 609 primary schools including 1,244 mono-grades and 724 multigrade classes or about 36.23\% (Province Education and Sports Service [PESS], 2017). Most of the multi-grade classes are gathered with two or three grades in 
the same classroom for instance, Grade 1+2, Grade 2+3, Grade 4+5, and/or Grade 1+2+3. According to the reports of the Salavan District Education and Sports Bureau (DESB), the number of teachers who teach the multi-grade class in Salavan District is higher than other districts compared in the whole country. Most of the teachers who have participated in training have done so about one to three times during last decade. The DESB is not often used to provide the training program; it often uses the Pedagogical Advisor (PA) to help teachers at the local schools. They have found that many teachers have faced considerable problems in the classroom, and they have exchanged their experiences and new ideas about improving the teaching skills. However, they still do not have a deep understanding of how to teach multi-grade. Thus, it has affected the student learning outcomes which are at a minimal level. In addition, many teachers do not usually develop a lesson plan (District Education and Sports Bureau [DESB], 2015a). The main problems the DESB found came from the condition of the village school's learning resources. In order to rectify these problems, teachers need a deeper understanding of the teaching of multi-grade classes. The DESB insists that the background of the problem is the teacher. The latter did not have a through understanding of how to teach multi-grade; they are not confident of their teaching and problems, including the preparation of lesson plans, the teaching methodology, and organization of the classroom add to the difficulties. Only $50 \%$ of teachers made a lesson plan and prepared the teaching and learning materials. Most of the lesson plan that they had developed for two or more grades were recorded in one book. Much of the teaching methods which teachers used was asking and answering question, the teaching and learning activities in which students get more participation are very few. Teachers tended to remain mostly in front of the class, inclined to talk most of the time, and just asked some questions of their students. Teachers often asked the students questions which did not encourage students to think and express their own views. In terms of controlling the several classes at the same time, teachers started to teach a lesson with the lower grade first while the others were waiting, often for ten minutes or more. In some classes which consist of three grades, students at grade three will spend twenty minutes waiting for the teacher. Teachers did give students some time to work in groups within their own grade or mixing with others (National Assessment Student Learning Outcome [NASLO], 2014, Holt, 2012).

Following on from the problems demonstrated above, it is clear that the majority of the teachers lack the knowledge and skills for organizing the teaching and learning activities effectively. They are not confident about their experience, and also, they do not have deep understanding of how to make or create a lesson plan which can help them to accomplish their learning objectives. Therefore, the purpose of this study is to improve and enhance the teachers' skills in preparing a lesson plan, organizing the classroom, and testing out teaching practice based on their experience and new knowledge and skills which have been gained from their training. The teaching method approach that was used is the Lesson study model. 
The following two research questions are addressed in this study: (1) How can teachers professional knowledge and skills be improved? (2) Does Lesson study, work for enhancing the teachers' professional development?

\section{The idea of Lesson study}

Lesson study is a teaching improvement process that has its origins in Japanese elementary education. Its objective is to improve and develop the teacher's professional knowledge and skills in teaching in which teachers work together in planning, observing, analyzing, and refining actual classroom lessons. This form was called a "research lesson." A research lesson means one team member conducts a research lesson, while others observe and collect data. And at the end of the lesson, teachers reflect on how students responded to the lesson by using data (Lewis, 2006).

At the present, the Lesson study is a popular professional development model approach both in Japan and others countries as it has come under increasing attention from educators from the West and throughout Southeast-Asia. This is because it is revealed outside Japan through the release of the Trends in International Mathematics and Science Study (TIMSS) and the video study (Groves, 2011). The effect of the teachers' professional development through the Lesson study was found to be outstanding throughout the world. For example, the Asia-Pacific Economic Cooperation (APEC) human resource working group, and APEC-Tsukuba International Conference have run challenges for the Lesson study movement project in some countries such as the US, Singapore, Chili, and Thailand. The project adopted five years Lesson studies in mathematics and science education. The results showed that teachers can deepen understanding about their teaching and learning activities as well as change their thinking and behavior after they undertaken the Lesson study. Most of the teachers who discussed and shared ideas based on the theme of the Lesson study appeared to learn and develop new ideas. The results of the project indicated that more than $80 \%$ of participants agree that Lesson study is useful for the teachers and students in improving of the quality of mathematics and science teaching (Masami Isoda \& Maitree Inprasitha, n.d.).

In Lao PDR, Lesson study has been used to improve and develop the teachers' professional development framework in mathematics and science subjects in the three provinces, of Khammuan, Savannakhet, and Champasack in the school year 2013-2014. Then the Lesson study approach was used for the student teacher programs in the Teacher Training Colleges (TTCs) especially for the mathematics and science subject fields. For example, Phailath et al. (2017) did two studies about the effectiveness of using Lesson study to build the pedagogical knowledge and improve the teaching in the mathematics lesson. It also assisted in the professional development of mathematics teachers through. Both studies confirmed that the cycle of the Lesson study model can have an impact on the teachers and engaged student learning outcomes.

Based on the Lesson study step which was proposed by Catherine Lewis (2002), this study has adapted into seven steps including: problem analysis, training 
planning, training implementation, creating and analyzing the lesson plan, teaching practice, reflecting and improving, and evaluating (See Figure 1).

Step1: problem analysis; collect and analyze the teacher's teaching problems in multi-grade classes from the national reports, region reports, and the results of from the PA (Pedagogy advisor).

Step2: training planning; it was provided on day one in order to understand the main purpose of the training including the objective of the training, contents, and strategies of training teaching of multi-grade.

Step3: training implementation; was in two parts; 1) reviewing and exchanging about the experience of teaching multi-grade. 2) Introducing how to teach multigrade classes.

Step4: create and analyze the lesson plan.

Step5: teaching practice; teaching practice in the real classroom

Step6: reflection and improving; using observation, comments, and opinions from participants as feedback.

Step7: evaluation; using pre and post survey questionnaires

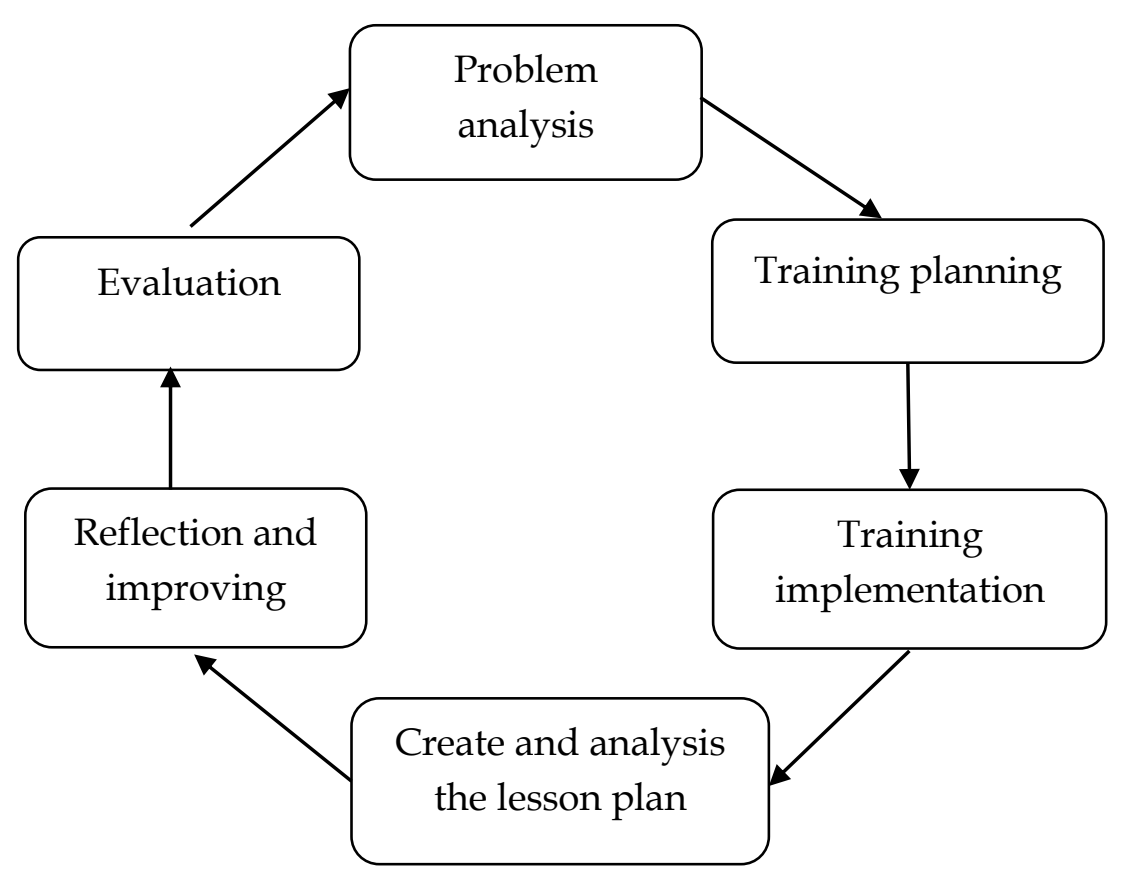

Figure 1: The road map of Lesson study approach

\section{Methodology}

According to the lessons learned from the previous implementation of training strategies, the Head of Salavan PESS and Head of Salavan DESB were in agreement to approach the Lesson Study method to solve the problems associated with multi-grade classes. It had been determined that the best way to affect the improvement of teachers' skills in the teaching multi-grade is Lesson 
Study. This involves trainees focusing on the main points of teaching and learning activities especially on the creation of lesson plans, classroom management and teaching methodology. These are the issues most teachers are focused on. Before implementation of the training program, DESB provided one day for discussion and determination of how to organize the training through Lesson Study. It was agreed that the teachers of Salavan District would be divided into 4 groups, each group consisting of about fifty teachers, and each group from different locations. The goal of this study was focused on only two groups because the number of teachers in each group was similar and the training content, teaching method, and activities were the same. Each group had four trainers but a researcher joined in the first group with three trainers. The evaluation survey questionnaires for both pre and post-training were the same. Every group completed the answers in the questionnaires. As the number of teachers, their experience and the school's situations were similar it was decided to use the results from just two of the groups.

The training process was arranged over three days, the first day reviewed the problems that teachers met in their classroom and introduced some new ideas to solve these problems. On the second day, teachers made and analyzed the lesson plan. The class was divided into six groups, each group chose one topic from mathematics, Lao language or science. The best lesson plans were chosen to pilot in the real classroom. This consisted of mathematics and Lao language for grade $1+2$ and mathematics and science for grade $3+4$. On the third day, there was teaching practice at the primary school. All teachers who belonged to the teaching group were to help each other, and the other groups were observing. After finishing the lesson feedback was given by the observers. Subsequently a post survey questionnaire was completed by the teachers.

\subsection{Participants}

There are 210 teachers in Salavan district, Salavan Province who were teaching multi-grade classes in the academic year 2017-2018. Accordingly, the study plan for this training program the teachers were divided into four groups; the first group being 53 teachers, the second 47 teachers, the third 57 teachers, and the fourth group 54 teachers. The target participants of this study were focused on the first two groups of 100 teachers.

\subsection{Research instrument}

The instruments consisted of teaching skills evaluation sheets both pre-training and post-training. They were utilized to compare the progress, understanding and the abilities of teachers during the training period. The instrument consists of four contents with 23 items of indicators: 7 items for lesson plan preparation; 6 items classroom organization; 7 items for teaching practice; and 3 items time management. This evaluation sheet was adapted from multi-grade teaching training handbook which was conducted by the Ministry of Education and Sports (MoES, 2010). Each item has a measuring scale from 1-5, where 1 represents the lowest agreement, and 5 represents the highest agreement. Other evaluation tools that were used included observation sheets and video recordings. The statistics employed to analyze the quantitative data were mean, 
standard deviation, while qualitative data were analyzed through content analysis.

\subsection{Data collection}

The data collection that was used is the pre and post survey questionnaires, observation hand records, and video recorder. The methodology of this study was followed by the stage of a Lesson Study. Before starting the training, the researcher and trainers explain the purpose of the questionnaire and asking which items that participants did not clearly understand. Then all of participants completed the answers on the questionnaire. At the end of the training, all of participants completed the post questionnaire. Most of the questionnaires received were completed by the four groups. The observations were hand recorded in notebooks, these were then analyzed for words with a high frequency of use. And the video recorder was using smart phone. These results were shared with the other groups.

\subsection{Data analysis}

In order to measure the viewpoints of the sample on the perspective, effectiveness and feasibility of the training as Lesson study to improve and enhance teaching skills of the teachers, percentages were used to compare the differential of the teachers' demography and mean, standard deviation and paired-simple t-test were used. The analysis data application used SPSS program (Trail version). In order to proof two research questions, researcher tested the compare Mean between pre and posttest by defined significant level at $\alpha=.05$ the qualitative data was used collecting the keywords by counting the frequency of words from observations, commendations and group discussion.

\section{Results}

According to the purpose of this study, the results were received from pre and post survey questionnaires, and observations (hand recorded). The quantitative data were completed by the participants, and the qualitative data were gathered from researcher and trainers.

Table 1: The demography of participants

\begin{tabular}{|c|c|c|c|}
\hline Contents & Items & N & Frequency (\%) \\
\hline \multirow{2}{*}{ Gender } & Male & 52 & 52.31 \\
\cline { 2 - 4 } & Female & 48 & 47.69 \\
\hline \multirow{3}{*}{ Teaching Experience (years) } & 1 to 5 & 57 & 56.66 \\
\cline { 2 - 4 } & 6 to 10 & 31 & 31.41 \\
\cline { 2 - 4 } & More than 10 & 12 & 11.92 \\
\hline \multirow{3}{*}{ Used to trained (year) } & 1 to 3 & 97 & 97.05 \\
\cline { 2 - 4 } & 4 to 6 & 2 & 2.09 \\
\cline { 2 - 4 } & More than 6 & 1 & 0.95 \\
\hline
\end{tabular}




\begin{tabular}{|c|c|c|c|}
\hline \multirow{4}{*}{ Teaching Class } & Grade1+2 & 25 & 24.79 \\
\cline { 2 - 4 } & Grade2+3 & 16 & 16.06 \\
\cline { 2 - 4 } & Grade3+4 & 12 & 11.68 \\
\cline { 2 - 4 } & Grade4+5 & 24 & 24.09 \\
\cline { 2 - 4 } & Grade1+2+3 & 23 & 23.38 \\
\hline
\end{tabular}

Table 1 shows that the males' and females' numbers are not different to a significant extent (male 52.31\% and female 47.69\%). Most of the teachers have experience of between 1 to 5 years $(56.66 \%)$, this is followed by teachers with 6 to 10 years' experience (31.41\%). For the used to train, almost all teachers $(97.05 \%)$ have been trained for 1 to 3 times. The number of teachers who teach Grade 1+2 and Grade $4+5(24.79 \%$ and $24.09 \%)$ is greater than those teaching Grade $2+3$ and Grade $3+4(16.06 \%$ and $11.68 \%)$ but similar to those teaching Grade $1+2+3$ $(23.38 \%)$.

Table 2: The result of paired-sample T-test to enhance the teaching skills Concerning the Pre-test Scores and Post-test Scores of the training group 1

\begin{tabular}{|c|c|c|c|c|c|c|}
\hline \multirow{2}{*}{ Items } & \multicolumn{2}{|c|}{ Pre-test } & \multicolumn{2}{c|}{ Post-test } & $\mathrm{t}$ & $\mathrm{p}$ \\
\cline { 2 - 7 } & Mean & SD & Mean & SD & & \\
\hline Preparing a lesson plan & 3.41 & 0.33 & 4.04 & 0.15 & -7.12 & $0.00^{*}$ \\
\hline Organizing the classroom & 3.37 & 0.37 & 3.79 & 0.27 & -8.01 & $0.00^{*}$ \\
\hline Teaching practice & 3.37 & 0.14 & 3.96 & 0.09 & -10.97 & $0.00^{*}$ \\
\hline Time management & 3.17 & 0.06 & 3.89 & 0.03 & -15.50 & $0.00^{*}$ \\
\hline
\end{tabular}

Key: ${ }^{*}=p$ value significant at the 0.05 level

Table2 shows that the average scores of pre-tests of four items (preparing a lesson plan, organizing the classroom, teaching practice, and time management) are at the middle level compare to full score (Mean between $3.17-3.42$, and SD between $0.06-0.37$ ). The average scores of post-test of four items are a little bit higher compared to pre-test (Mean between 3.79 - 4.04, and SD between 0.03 0.27). The highest of average scores of post-test is a preparing a lesson plan $($ Mean $=4.04)$, and followed by time management $($ Mean $=3.89)$. The compare mean pared-sample $t$-test ( $\mathrm{t}$ between -7.12 to -15.5), and it was defined $\alpha=0.05$, found $p=0.00$, determined that $p$ value significant at the 0.05 level. 
Table 3: The result of independent sample T-test to enhance the teaching skills as to the Pre-test Scores and Post-test Scores of the training group 2

\begin{tabular}{|c|c|c|c|c|c|c|}
\hline \multirow{2}{*}{ Items } & \multicolumn{2}{|c|}{ Pre-test } & \multicolumn{2}{c|}{ Post-test } & $\mathrm{t}$ & $\mathrm{p}$ \\
\cline { 2 - 7 } & Mean & SD & Mean & SD & & \\
\hline Preparing a lesson plan & 3.12 & 0.30 & 4.15 & 0.31 & -6.90 & $0.00^{*}$ \\
\hline Organizing the classroom & 3.33 & 0.40 & 3.93 & 0.36 & -10.55 & $0.00^{*}$ \\
\hline Teaching practice & 3.22 & 0.11 & 4.00 & 0.08 & -16.37 & $0.00^{*}$ \\
\hline Time management & 3.21 & 0.05 & 4.02 & 0.14 & -9.04 & $0.01^{*}$ \\
\hline
\end{tabular}

Key: ${ }^{*}=p$ value significant at the 0.05 level

Table3 shows that the average scores of pre-test of four items (preparing a lesson plan, organizing the classroom, teaching practice, and time management) are at the middle level compare to full score (Mean between 3.12 - 3.42, and SD between $0.05-0.4)$. The average scores of post-test of four items are a little bit higher compared to pre-test (Mean between 3.93 - 4.15, and SD between $0.08-$ 0.36). The highest of average scores of post-test is a preparing a lesson plan (Mean $=4.15)$, and followed by teaching practice and time management (Mean = 4.00 - 4.02). The compare mean pared-sample $t$-test ( $\mathrm{t}$ between -6.90 to -16.37 ), and it was defined $a=0.05$, found $p=0.00$, determined that $p$ value significant at the 0.05 level.

The result of the observations, group commendations and group discussions determined that during the first day most teachers had experiences of teaching multi-grade class. The frequency of the problems such as lack of techniques for teaching, not understand how to make a lesson plan, teaching method approach, and time management were higher than other problems. The results on the second day found that many teachers were confused and lacked confidence in making lesson plans. The third day was teaching practice at the multi-grade school, most of results from the observations indicated that teachers taught as they used to use in their own school. It seemed difficult to follow the new ideas which they had incorporated into their lesson plans. From the results of the observations and comments of teachers it was determined that teachers understood how to develop a lesson plan, how to organize the class, and undertake time management which they received during the training. However, most of all teachers complained that if they got more opportunities for training or sharing experience on teaching or working in multi-grade class it might be more effective in getting higher level of student learning outcomes.

The other problems that appeared was that most of the teachers do not like to prepare or make lesson plans; they usually organize the teaching and learning activities by using the teachers' handbook. They said they had many responsibilities for their family and school. Therefore, they did not have the time or the energy to prepare proper lesson plans. In addition, the majority of the 
teachers spent a lot of the time lecturing and asking students questions. For example, a result of observation from one class found that the teacher used the student learning-center method, and the assignments those teachers gave to the students did not fit with the time, at the same time some students did not understand what the teacher wanted them to do. In addition, while the teacher did an interesting activity with students of grade 4, the students of grade3 were watching them. It seemed they were not interested with their own assignment. The result of the observation and group discussions also showed that many teachers are not confident with the teaching practice as they said that they were confused with the approach, the new ideas of teaching and learning activities which they received from the training, because they could not follow their lesson plan when they did teaching practice. Thus, they could not control the time for each stage of each grade.

\section{Discussion}

This study aimed to find out the strategy to improve teachers' professional knowledge and skills in multi-grade teaching and try out about the effects of Lesson study work for enhancing the teachers' professional development. It discusses how teachers prepare a lesson plan, organizing classroom, teaching practice, and time management during teaching practice. And also discusses how Lesson Study effect to the training program. The discussion results were based on the evaluation sheets, observations, and opinion from the group discussion which have been sharing and comparing with other situation of multi-grade teaching development and lesson learned from abroad. For the part of the "Time management" was not necessary to discuss, because it was related to the three main parts of this study including preparing a lesson plan, organizing the classroom, and teaching practice.

Research question1: How can teachers' professional knowledge and skills be improved?

\section{1) Preparing a lesson plan}

A lesson plan is necessary for the teacher because the teacher will be able to outline the objectives for the learners that teachers have gathered from the national curriculum or the competency of each subject matter. It still makes sense for most multi-grade teachers to prepare or conduct a lesson plan because of the limited time, teaching more than one class, and the lack of support teaching materials. According to Tables 2 and 3, the results from the group discussions show that most teachers understand how to prepare a lesson plan but teachers did not understand sufficiently about the concept of the studentlearning center method. They were confused as they conducted the lesson plan and with the approach to new teaching methods. The representation about group performance on making a lesson plans were different. Most groups were confused on the first stage of the teaching procedure and the setting of the time for each stage. Referring to the DESB trainers' reports, teachers who teach multigrade faced more problems than mono-grade, they conducted their lesson plan as best they could. This is the same result found from the Educational Standard and Quality Assurance Center (ESQAC) where they conducted research in remote districts in Bokeo province on teaching practice and learning outcomes of grade 3 . They reported that most teachers did not understand how to set the 
objectives and learning outcomes for the lesson, many teachers had never seen the curriculum textbook and they did not know what the curriculum actually was. At the same time, teachers did not usual make a lesson plan because they did not understand adequately how to develop it (Educational Standard and Quality Assurance Center [ESQAC], 2011). According to the reports from the DESB and the results of this study it was found that multi-grade teachers do not like to make a lesson plan because they believe that preparing a lesson plan consumes considerable time and equipment. Another reason is that they are confused about how to make a lesson plan for teaching multi-grade classes. The current formats of the lesson plan suits a teacher who has limited time but in order to prepare and develop a lesson plan, the teacher should make a clear plan to conduct or develop lesson plan for each subject. They can spend time during the school summer break to undertake this task.

A lesson learned from abroad, is that a lesson plan is a written description of the process; where the materials, the method, the time and the place of education as well as methods for evaluating the students are described in detail. Lesson planning communicates to learners what they are to learn and how their goals will be assessed, and it helps instructors organize the content, materials, time, instructional strategies and assistance in the classroom (Teaching Excellence in Adult Literacy [TEAL], 2010). Lesson planning is at the heart of being an effective teacher. It is a creative process that allows us to synthesize our understanding of second language acquisition and language teaching pedagogy with our knowledge of our learners, the curriculum, and the teaching context. Most educators are determined that a lesson plan is important, and it is effective to the student learning outcome. Ali Jamali Nesari \& Mina Heidari (2014) studied the Important Role of Lesson Plan on Educational Achievement of Iranian EFL Teachers' Attitudes, they found that most English teachers agreed with utilizing lesson plans and in addition they took an interest in making the lesson plan. According to the TEAL (2010) they suggested that teachers should focus on one objective at a time and communicate to learners what will be imparted in each subject. Then the teacher designs what will taught in each stage of the teaching procedure. Thus, it is determined that the lesson plan has an effective role in the quality of teaching of teachers, and student learning outcomes.

\section{2) Organizing the classroom}

In particular, the multi-grade class in each region in Lao PDR looks quite similar. Only some of them are different depending on the remote areas and poor conditions. In Salavan district, Salavan province, about $30 \%$ of multi-grade classrooms are not easily accessible; these schools have considerable problems for the teachers to organize the teaching and learning activities (DESB, 2017). The results of Tables 2 and 3 and the outcome from the group discussions show that many of the teachers understand about organizing or arranging the classroom to give facilities for teaching and learning activities. However, the real classroom does not easily facilitate the classroom which is appropriate for the new teaching methodologies. This study found that teachers did not believe that organizing the classroom would influence the students learning outcome. They 
arranged the classroom for the ease of their own teaching. The organization of the classroom to facilitate teaching in multi-grade classes should be designed differently to the mono-grade classroom. In Lao PDR, the arrangement of the classroom depends on the condition of the schools building. If the village has a permanent building, teachers might be comfortable arranging the class in a manner suitable for the student-learning center methods. Those villages without permanent buildings have particular difficulties in arranging the classroom in a suitable manner for multi-grade teaching methodology. It was found in this study that many teachers did not know how a classroom could be arranged for effective multi-grade teaching. Most of the current multi-grade classes had all the desks in rows facing in the same direction rather than the different grades sitting in different directions or groups. Many researchers have noted that the traditional classroom with rows does not work well (UNESCO, 2015b). It is indicated that the current multi-grade classroom will not work well for the teacher and student. Miller (1990) proposed that organizing the classroom for the multi-grade class is very important and necessary because the varied ages of students and the variable size of the classrooms. He has suggested that classroom arrangement must be flexible to accommodate new learning activities. He further claimed that when organizing the classroom, teachers should ensure that activities will occur in each working area will be supported by the equipment and materials available, thus teacher should 1) understand the space in the classroom and the resources available for conducting class; 2) decide on the kinds of teaching methods and student activities possible in the space available given the number of students and grades in the classroom; and then 3) design a floor plan of the classroom with a seating plan that promote teaching and learning activities.

\section{3) Teaching practice}

According to the results of Table 1, most of the teachers have teaching experience of around one to five years; and most of them have between one to three times participated in training and about $23 \%$ of teachers taught three grades. Most of the teachers have for many years found the work challenging even with this experience. Teaching practice is hard work for the teacher who teaches more than one grade. The results of this study found that most of the teachers are teaching by following the instruction stage on their handbook. Those teachers who often make a lesson plan are skilled at creating a lesson plan, and they are also doing teaching practice very smoothly. This means that the teachers who understands adequately about preparing or creating a lesson plan will work and teach their students to a higher standard in the classroom. As already mentioned about that teachers who do not usually prepare a lesson plan, their teaching practice fails to accomplish its desired goals. From the observation results it was found that teachers did not fully understand about how to provide the teaching and learning activities which are appropriate to the student's knowledge level, nor how to create ideas to improve or increase the progress of student's knowledge and skills especially using the student-learning center approach. These problems occurred also for teachers who teach in mono-grade. The DESB reported that they have been making efforts and advising teachers on how to improve their professional skills however it made little change from the 
results of previous studies as they found that teachers questioned and talked too much in the class and many students did not actively participate in the lesson. It was only a few students who responded to the teacher. (LuiBenvenist, 2005, Holt 2012, and NASLO III, 2014). Teachers found teaching in a multi-grade context challenging and difficult (Joyce, 2014). The additional evidence of the video recordings indicates that many teachers lack confidence in their teaching practice, it appears that they were confused about the procedure of the teaching stages even when they had prepared properly. Most teachers said that they were not familiar with using the new teaching and learning methods in addition they used what they believed and what they had learned from their experience. To enhance teachers' professional development, teaching practice techniques are the first priority for multi-grade teachers. In addition, this study found that if teachers update or exchange their experiences frequently it will provide them with the best teaching and learning activities. They want to have more support from the PESS and DESB to enhance their knowledge and skills of teaching multi-grade class. A lesson learned from Miller (1990) suggested that teachers have to understand the new teaching methods and be more flexible in their classroom techniques. At the very least teachers should approach three kinds of strategies; 1 ) instructional delivery and grouping (these consists of strategies that organize the groups to learn activities across and within grade level), 2) selfdirected learning (this for developing skills and strategies in students that allows for a high level of independence and efficiency in their learning) and 3) peer tutoring (this method is about developing skills and a routine where a student serves as a teacher to other students within and across different grade levels).

Research question 2: Does Lesson study work for enhancing the teachers' professional development?

According to Tables, 2 and 4 the training outcomes for both groups are significantly different. This study found that training teachers through the Lesson study method is suitable for enhancing the teachers' professional skills because the researcher and the instructors focused on the main problem of teaching skills which follows the cycle of the Lesson study such as the collection and analysis of the main problems which teachers are meeting in their classroom. They then defined the strategies to solve those problems by concentrating on the plan-do-see cycle as all teachers have been exchanging the conditions, problems and experiences and further make a lesson plan, analysis the lesson plan, and subsequently take it to the real classroom to see the result. The teachers then analyze the advantageous and disadvantageous points to discuss and determine whole opinions for new innovation for teaching practice. Lesson study is believed to be an effective model of professional development (Puchner, 2006). It shows that the planning and work of the teachers can have an impact on student engagement in the classroom. Most studies have shown that the Lesson study method can have a positive impact on the in-service teacher and can provide the opportunities to build professional learning communities and deepen understanding of content and pedagogy (Mostofo, 2014). There were various strategies to enhance the teachers' professional development, however, the Lesson Study was effective for this study as well as results from the review of studies from 2000 to 2010 which identified positive evidence 
supporting the benefits of Lesson Study and Learning Study as powerful tool to help teachers examine their practices and enhance student learning. Although all nine studies showed positive effects of Lesson Study and Learning Study on teaching, learning or both, different outcome measures were employed and the study designs varied in quality (Ming Cheung, 2014).

The Lesson study is popular for developing the teaching skills in Japan, the United State, and others countries. In Lao PDR, the Lesson study approach started many years ago but it was not widely expanded. Right now, most teacher training colleges are promoting teachers to approach the Lesson study to build pedagogical knowledge and improve teaching skills, particularly in a mathematics lessons. In order to improve and develop the teachers' professional knowledge and skills for the multi-grade class which provides the training schedule approach, the Lesson study is useful. Most teachers have deepened their understanding of the teaching techniques and stages in the multi-grade class using this method. It was also found that in order to deeper understand about what will be taught for each grade and how to produce the materials could be undertaken by teachers doing the planning during the summer holidays and this will mitigate their time management for their daily teaching schedule.

\section{Conclusion and recommendation}

According to the results of this study, teachers still need more ability both knowledge and skills to teach multi-grade. The data in Table 1 shows that most teachers practiced training about teaching multi-grade 1 to 3 times and at the same time the number of teachers who teach more than two grades is also high. This situation results in the teachers meeting increased challenges in the classroom. In order to continue to improve the teachers' professional knowledge and skills, training methods which uses the Lesson study approach is effective, and it will be better if a training schedule can be provided every year. The results of this study also found that the situation of multi-grade teaching in Lao PDR still faces many challenges such as the condition of the classroom, the opportunities for participation in the training and the teachers' school administration skills, especially in remote and/or separate schools. Therefore, training is still the primary strategy to improve the teachers' professional knowledge and skills. Teachers who did not participate the training on multigrade teaching would find teaching more difficult than others (Taole, 2012). In order to improve the quality of multi-grade teaching, reform or rebuilding the education in the rural areas is needed. Such a lesson has been learned from the Chinese. The Chinese government has attached importance to the quality of personnel practicing multi-grade teaching and sought to enhance their teaching abilities in diverse ways, including training at teacher training schools, in-service training, and action research. From 2001 to 2009, the governments had adjusted the multi-grade school distribution by improving the school condition, adjustment and amendment to policies relating multi-grade teaching, and the government put great emphasis on restructuring and optimizing school resources allocation. At the same time, the Chinese government put emphasis on ICT support to multi-grade teaching to actively realize the universalization of compulsory education. Since 2010, the multi-grade teaching in China has 
continued to reform and develop. In recent years, most multi-grade schools in China implemented the "Project of Full Access to Digital Education Resources", equipping the rural teaching points with digital resources. The project of digitalization make it possible to have access to quality digital education resources (UNESCO, 2014). It shows that the multi-grade teaching in China is one lesson learned that could be a good example for improving the quality education in the rural areas in Lao PDR.

In addition, in order to ensure the quality of teaching for multi-grade class, the Teacher Training Colleges (TTCs) should adopt the curriculum of the primary school student which concentrates on how pre-service teachers can deepen their understanding about teaching multi-grade as there are many pre-service teachers facing considerable problems in their first or second year of teaching in local schools. Many teachers have said that they were not confident teach1ng the multi-grade class; most of them wish to teach mono-grade as much as possible. Therefore, the TTCs should consider how to improve knowledge and skills on teaching the multi-grade class for the new teachers before they go to teach at their local school. According to the results of this study, the future research might study how to promote or improve the school administration, and how to promote teachers using Information Communication and Technology (ICT) applications for teaching and learning activities both for mono-grade and multigrade which can decrease the teachers work load.

\section{References}

Amali Nasari, A., Heidari, M. (2014). The Important Role of Lesson Plan on Educational Achievement of Iranian EFL Teachers' Attitudes. International Journal of Foreign Language Teaching and Research, 2(5), 25-31. Retrieved from http://jfl.iaun.ac.ir/article_10884_43a5ff2bb7fbd6998f091eb726f80104.pdf

Catherine Lewis. (2002). Brief Guide to Lesson Study. Education Department, Mills College, Oakland CA. retrieved from http://www.lessonresearch.net/briefguide.pdf

Christian Munro \& W. John Howe. (2013). Strenthening Local Governance and Participant for the Realization of Children's to Education: Final Evaluation 2013. Retrieved from https://planinternational.org/sites/files/plan/media_wysiwyg/plan-lao-educationeubasiceducationprojectbokeo-evaluation-eng-aug13.pdf.

District Education and Sports Bureau. (2015a). Five years report (2011-2015): Evaluation of Education Deveploment Plan. Salavan District, Salavan province, Lao PDR.

District Education and Sports Bureau. (2017b). Annaul report for academic year 20162017: The academic report (2016-17). Salavan District, Salavan province, Lao PDR.

Educational Standard and Quality Assurance Center. (2011). Research report: Teaching practice and learning outcome, grade 3 two districts in Bokeo province, Lao PDR.

Groves, B. D. (2011). Japanese Lesson Study: Teacher Professional Development through Communities of Inquiry. Mathematics Teacher Education and Development, Vol. 13.1, 77-93. Retrieved from https:/ / files.eric.ed.gov/fulltext/EJ960950.pdf

Holt, W. J. (2012). Strenthening Basic Education Project: A Study of Multi-grade Teaching Practices within two Districts of Bokeo Province. Retrieved from 
https://plan-international.org/sites/files/plan/media_wysiwyg/plan-laoeducation-multigradeteachingpracticesbokeo-study-dec12_0.pdf

Joyce, T. M. (2014). Quality Basic Education for All: Challenges in Multi-Grade Teaching in Rural Schools. Mediterranean Journal of Social Sciences. doi:10.5901/mjss.2014.v5n1p531

Lao-Australia Basic Education Project. (2008). Final report: Annual program performance report for the Lao People's Democratic Republic 2007-08. Retrieved from https://dfat.gov.au/about-us/publications/Documents/appr_laos_07.pdf

Lewis, C., Perry, R., \& Murata, A. (2006). How Should Research Contribute to Instructional Improvement? The Case of Lesson Study. Educational Researcher, 35(3), 3-14. doi:10.3102/0013189x035003003

Ley, S. V. (1999). Book 2: Classroom Organization. In B. A. Miller, the multigrade classroom: A research hanbook for small, rural school(pp.1-18). Portland, Oregon 97204: Northwest Regional Education Laboratory.

Lui Benveniste, J. M. (2005). Teaching in Lao PDR. Human Development Sector. Vientiane, Lao PDR.

Masami Isoda \& Maitree Inprasitha. (n.d.). Retrieved from APEC: http://www.criced.tsukuba.ac.jp/math/apec/

Miller, B. A. (1991). A Review of the Quantitative Research on Multigrade Teaching. Research in Rural Education, Fall, Vol, 7. No. 1, pp. 1-8. Retrieved from http://citeseerx.ist.psu.edu/viewdoc/download?doi=10.1.1.544.9728\&rep=rep1 \&type $=$ pdf

Ming Cheung, W., \& Yee Wong, W. (2014). Does Lesson Study work? International Journal for Lesson and Learning Studies, 3(2), 137-149. doi:10.1108/ijlls-05-20130024

Ministry of Education. (2010). Multi-grade Teaching Training Handbook. Department of Teacher Education. Vientiane, Lao PDR.

Ministry of Education. (2014a). Report on National Assessment of Student Learning Outcomes for Grade 3. Research Institution for Education Sciences. Vientiane, Lao PDR.

Ministry of Education and Sports. (2017). Annual School-Sensus 2016-2017. Vientiane, Lao PDR.

Ministry of Education. (2014b). Report on National Assessment of Student Learning Outcomes for Grade 5. Research Institution for Education Sciences. Vientiane, Lao PDR.

Taole, M., \& Mncube, V. S. (2012). Multi-grade Teaching and Quality of Education in South African Rural Schools: Educators' Experiences. Studies of Tribes and Tribals, 10(2), 151-162. doi:10.1080/0972639x.2012.11886653

Mostofo, J. (2014). The Impact of Using Lesson Study with Pre-Service Mathematics

Teachers. Journal of Instructional Research, Volume 3, 55-63. Retrieved from https:// files.eric.ed.gov/fulltext/EJ1127641.pdf

Province Education and Sports Service. (2017). The summary of academic year 2015-2016 and planing for academic year 2017-2018. Salavan province, Lao PDR.

Philath Sythong, Phimmasone Vorayouth \& Inthanome Phavady. (2017). The effectiveness of using lesson study to building pedagogical knowledge and improving teaching in mathematics lesson: A case study in savannakhet teacher training college. Academic journal of Savannakhet teacher training college, Volume, 1. Retrieved from http://savannakhet-ttc.edu.la/analysis/i1/ 
Puchner, L. D., \& Taylor, A. R. (2006). Lesson study, collaboration and teacher efficacy: Stories from two school-based math lesson study groups. Teaching and Teacher Education, 22(7), 922-934. doi:10.1016/j.tate.2006.04.011

Teaching Excellence in Adult Literacy. (2010). Effective Lesson Planning. Retrieved from https://lincs.ed.gov/sites/default/files/8_TEAL_Lesson_Planning.pdf

United Nations Educational, Scientific and Cultural Organization. (2014). Promoting Quality Learning through Enhanced Multi-grade Teaching in the People's Republic of China: Review Report. Retrieved from http://www.unescobkk.org/fileadmin/user_upload/appeal/IE/Meeting_and_ Conference/Multigrade_Teaching_2014/Desk_review/Desk_review_status_of_ MGT_in_China.pdf

United Nations Educational, Scientific and Cultural Organization. (2015a). The 2015 Global Monitoring Report - Education for All 2000-2015: Achievements and Challenges. Retrieved from http:// unesdoc.unesco.org/images/0023/002322/232205e.pdf

United Nations Educational, Scientific and Cultural Organization. (2015b). Practical Tips for Multigrade Teaching Classes. 7, place de Fontenoy, 75352 Paris 07 SP, France. Retrieved from http://unesdoc.unesco.org/images/0022/002201/220101e.pdf

United Nations International Children's Fund. (2000). Evaluation Report for the Teacher Upgrading Program. Retrieved from https://www.unicef.org/evaldatabase/files/2000_Laos_Teacher_rec_357803.pd $\mathrm{f}$

United Nations International Children's Fund. (2009). Schools of Quality in the Lao PDR: An Evaluation 2009. Retrieved from https://www.unicef.org/eapro/Evaluation_of_SOQ_in_Lao_PDR_December20 09_small_size.pdf

World Bank Group. (2016). School Autonomy and Accountability. Systems Approach for Better Education Results: Country Report 2016. Retrieved from http://documents.worldbank.org/curated/en/775471496225301798/pdf/11535 1-WP-PUBLIC-ADD-SERIES-SABER-SAA-Lao-PDR-Country-Report.pdf

Yang, G., \& Yu, S. (2010). An exploratory study of the application of modern distance learning resources for rural elementary and middle schools in Western China: The case of three cities in Gansu Province. Frontiers of Education in China, 5(1), 37-49. doi:10.1007/s11516-010-0005-2 